\title{
What is Right and What is Wrong in the Environmental Governance Model? Environmental Regulations for Improving Environmental Sustainability Ratings
}

\section{Co jest dobre, a co złe w modelu zarządzania środowiskiem? Analiza przepisów środowiskowych dla poprawy jakości zrównoważenia środowiskowego}

\section{Jajat S. Ardiwinata ${ }^{*}$ Khalid Zaman ${ }^{\star \star}$, Abdelmohsen A. Nassani ${ }^{\star \star \star}$, Mohamed Haffar ${ }^{\star \star \star \star}$, Chairil Faif Pasani ${ }^{\star \star \star \star \star}$, Sriyanto Sriyanto ${ }^{\star \star \star \star \star \star}$}

\author{
*Universitas Pendidikan Indonesia, Department Community Education, Kota Bandung, \\ Jawa Barat 40154, Indonesia \\ Email: jsardipls@upi.edu \\ **University of Haripur, Department of Economics, Haripur Khyber Pakhtunkhwa, Pakistan \\ E-mail (Corresponding Author): khalid_zaman786@yahoo.com \\ ***College of Business Administration, Department of Management, King Saud University, \\ P.O. Box 71115, Riyadh, 11587, Saudi Arabia \\ E-mail: Nassani@ksu.edu.sa \\ ****University of Birmingham, Birmingham, \\ Department of Management, Birmingham Business School, United Kingdom \\ E-mail:m.haffar@bham.ac.uk \\ *****Universitas Lambung Mangkurat, Mathematics and Science Education, \\ Banjarmasin 70123, Indonesia \\ E-mail: chfaifp@ulm.ac.id \\ ******Universitas Muhammadiyah Purwokerto, Social Studies Department, Purwokerto, \\ 53182, Indonesia \\ E-mail: sriyanto1907@ump.ac.id
}

\begin{abstract}
The improper allocation of economic and environmental resources damages the United Nations sustainable development Agenda, which remains a challenge for policymakers to stop the rot through efficient governance mechanisms. The study designed an efficient environmental governance framework by extending the different governance factors linked to the environmental sustainability ratings in the cross-section of 67 countries. The results of the two-regime based estimator show that environmental corruption (regime-1), environmental politics (regime2), and environmental laws (regime-2) negatively correlated with the environmental sustainability rating, whereas environmental democracy (regime-1 \& 2) positively correlated with the environmental sustainability agenda across countries. The government effectiveness and the country's per capita income both escalates environmental sustainability ratings. The results align with the Demopolis theory, the effective regulatory theory, and the theory of law and politics. The causality estimates show that environmental corruption and government effectiveness causes environmental politics and economic growth. In contrast, environmental democracy and environmental regulations cause a country's per capita income. The bidirectional causality is found between environmental regulations and environmental corruption on the one hand, while environmental regulations and environmental politics Granger cause each other on the other hand. The results show the importance of environmental regulations in managing
\end{abstract}


ecological corruption and politics across countries. The variance decomposition analysis suggested that environmental politics likely influenced the environmental sustainability agenda, followed by government effectiveness and environmental democracy for the next ten years. The study emphasized the need to design an efficient environmental governance framework that minimizes environmental corruption and enables them to move towards environmental democracy, stringent environmental laws, and regulations. Government effectiveness would mainly be linked to reducing corruption and political instability to achieve clean, green and sustainable development.

Key words: environmental sustainability rating, environmental governance indicators, environmental regulations, government effectiveness, switching regression

\section{Streszczenie}

Niewłaściwa alokacja zasobów gospodarczych i środowiskowych szkodzi Agendzie ONZ na rzecz zrównoważonego rozwoju, która pozostaje wyzwaniem dla decydentów, aby powstrzymać negatywne trendy za pomocą skutecznych mechanizmów zarządzania. W ramach tego studium opracowano efektywne ramy zarządzania środowiskiem poprzez rozszerzenie zakresu różnych czynników zarządzania związanych z ocenami poziomu zrównoważenia środowiskowego wśród 67 krajów. Wyniki pokazują, że korupcja środowiskowa (system-1), polityka środowiskowa (system-2) i prawo środowiskowe (system-2) ujemnie korelowały z oceną zrównoważenia środowiskowego, podczas gdy demokracja środowiskowa (systemy-1 \& 2) pozytywnie skorelowane są z Agendą zrównoważonego rozwoju środowiska w różnych krajach. Zarówno skuteczność rządu, jak i dochód kraju na mieszkańca podnoszą oceny zrównoważenia środowiskowego. Wyniki są zgodne z teorią Demopolis, efektywną teorią regulacji oraz teorią prawa i polityki. Szacunki przyczynowości pokazują, że korupcja środowiskowa i skuteczność rządu wpływają na politykę środowiskową i wzrost gospodarczy. W przeciwieństwie do tego, demokracja środowiskowa i regulacje środowiskowe powodują wzrost dochodu na mieszkańca. Dwukierunkowy związek przyczynowy występuje między regulacjami środowiskowymi a korupcją środowiskową z jednej strony, podczas gdy regulacje środowiskowe i polityka środowiskowa Granger są ze sobą bezpośrednio związane. Wyniki pokazują znaczenie przepisów środowiskowych w zarządzaniu korupcją ekologiczną i polityką w różnych krajach. Analiza rozkładu wariancji sugeruje, że polityka środowiskowa prawdopodobnie wpłynęła na program zrównoważonego rozwoju środowiska, a następnie skuteczność rządu i demokrację środowiskową przez następne dziesięć lat. W badaniu podkreślono potrzebę zaprojektowania skutecznych ram zarządzania środowiskiem, które zminimalizują korupcję środowiskową i umożliwią dążenie do demokracji środowiskowej, rygorystycznych przepisów i regulacji dotyczących ochrony środowiska. Skuteczność rządu byłaby powiązana głównie z ograniczaniem korupcji i niestabilności politycznej w celu osiągnięcia czystego, zielonego i zrównoważonego rozwoju.

Słowa kluczowe: klasyfikacja zrównoważoności środowiskowej, wskaźniki zarządzania środowiskowego, regulacje środowiskowe, skuteczność rządu

\section{Introduction}

The word Governance refers to the set of policies and strategies that countries utilize to attain broadbased economic growth. The governments exercise different action plans to stabilize socio-economic and environmental issues and govern sound institutional policies. It remains at six main dimensions, i.e., voice and accountability, political stability, government effectiveness, regulatory quality, the rule of law, and control of corruption. The estimates of the stated governance indicators fall in the values between -2.5 (weak) to 2.5 (strong), which shows variability in the governance performance across countries. The countries ranked based on their percentile ranking ranges from 0 (lowest) to 100 (highest) rank. The given estimates are helpful to monitor the country's governance position in each index and help reach strong governance performance (WGI, 2021). The efficient governance framework is vital to safeguarding environmental and natural resources that need to be comprehensive and practical in all aspects, for instance, from the evaluation phase to governing the environmental system (Bennett \& Satter- field, 2018). The governance framework should be collaborative, linked to addressing communities and stakeholders to move forwards to resolve environmental issues (Gieseke, 2020). Environmental justice and ecological sustainability are the main policy factors for utilizing the environmental governance factors. The power-sharing from governments to the local institutions, communities and non-governmental organizations improve the governance framework. The governance framework should be equitable, fair, transparent, liable, broad, integrated, competent, and efficient (Savage et al., 2020).

Every year, the World Bank Group published different Country Policy and Institutional Assessment (CPIA) reports, mainly focused on twenty essential rating factors, including human resource rating, business regulatory rating, debt policy, economic management, revenue mobilization, public resource equity, financial sector performance, fiscal policy rating, gender equality, macroeconomic management, social inclusion, environmental sustainability rating, property rights, public sector management, budgetary quality, public administration quality, social protection, structural policies, trade rating, and public 


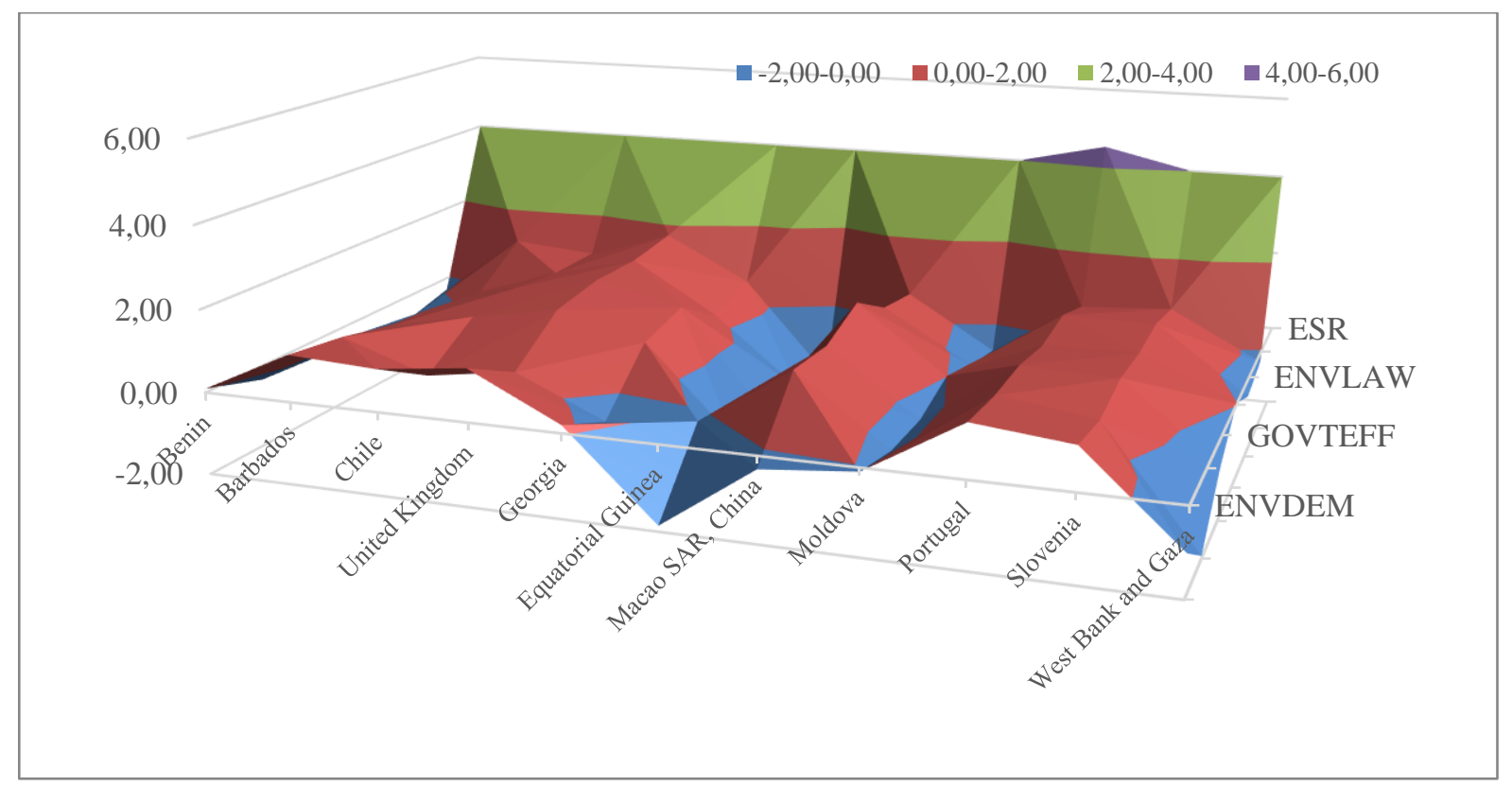

Figure 1. High-Rated Environmentally Sustainable Rating Countries (ESR $\geq 4)$ and Few Positive Environmental Governance Indicators, source: World Bank (2020). Note: ESR shows environmental sustainability ratings, ENVLAW shows environmental laws, GOVTEFF shows government effectiveness, and ENVDEM shows environmental democracy.

sector governance rating. The scale is fixed in between 1 (low) and 6 (high) sustainability ratings. The study selected environmental sustainability rating among the twenty stated rating indices directly linked with governmental environmental policies to conserve ecological and natural resources, leading to the sustainable use of ecological resources to control negative environmental externalities (World Bank, 2021). Figure 1 shows high-rated environmental sustainability rating countries with a value greater than equal to four (out of six). Benin economy, in many cases, has negative governance indicator values in environmental politics, government effectiveness, regulations, laws, and corruption, while a country has a positive value in democracy. Equatorial Guinea, Macao, Moldova, and West Bank \& Gaza have a negative value in democracy. Barbados, Chile, UK, Macao, Portugal, and Slovenia positively value political stability. Government effectiveness is weaker in the economies of Benin, Equatorial Guinea, Moldova, and West Bank \& Gaza. The positive value of environmental regulations has been found in Barbados, Chile, UK, Georgia, Macao, Portugal, and Slovenia. Environmental laws and corruption are mainly found in Benin, Equatorial Guinea, Moldova, and West Bank \& Gaza. Based on the crucial discussion, designing an efficient environmental governance framework is imperative to achieve a green and clean, sustainable agenda.

A more significant body of knowledge already exists for governance indicators and their impact on different socio-economic and environmental factors (Qureshi et al., 2019; Mazur et al., 2019; Adams et al., 2019). While very few scholarly works are pre- sent to design and evaluate an efficient environmental governance framework (Thaler, 2021; Dressel et al., 2021; Reed et al., 2021; Peker \& Ataöv, 2021). The present study builds an effective, sustainable environmental governance framework encompassing environmental justice and sustainability features to advance shared global prosperity. Cheng et al. (2020) argued that the Chinese economy faced severe difficulties in attaining environmental sustainability agenda because of the greater industrialization process, which ultimately increases emissions, water use and energy demand. The country is going forward to use a three-line environmental governance mechanism to minimize negative environmental externalities. The results conclude that efficient use of environmental governance framework would be helpful to attain the country's vision of green growth agenda. Van Assche et al. (2020) emphasized developing an efficient governance model that supports environmental integrity and sustainability to move forward towards global prosperity. Tang \& Geng (2020) stressed the need to improve the environmental governance process that linked it with the wideranging valuation process of natural resource management, mitigate pollution sources, government effectiveness to manage public resources, and lawful activities. Lawless et al. (2020) suggested that societal norms as a mainstream environmental governance framework. It includes holding human rights about environmental protection, unlocking women's potential in the mainstream of all public and private spheres, and environmental protection, equity, and ecological justice. These features help to maintain social dignity, leading towards humanity. Gupta et 
al. (2020) highlighted building an efficient governance framework that is accountable to the transparent system of public governance and moves forward towards attaining ecological conservation. Jager et al. (2020) discussed the positivity of the participatory and collaborative governance approach that likely influences ecological standards to meet the sustainability principle and is helpful for decisionmaking processes to reach out at some conclusive remarks. Ahmed et al. (2021) investigated the asymmetric relationship between governance factors and ecological footprints by using aggregated and disaggregate analysis in the context of the USA economy. The results show that economic globalization increases ecological footprints in a positive asymmetric shock while alleviates it with the negative asymmetric shocks. Further, positive shocks about social globalization improve environmental quality, linking it with political globalization to mitigate ecological footprints. The results emphasized the need to re-structure the environmental governance framework to absorb the negative environmental externalities of globalization worldwide. Moussa et al. (2021) considered a case study of the UK firms that publicly disclosed their environmental targets to perform efficiently in environmentally friendly production. The results show that the UK forms although compassionate about the environment and keen to achieve environmental set targets; however, there is greater variability and inconsistency reported about their disclosure of environmental targets. The results underlined the need to improve corporate disclosure policies about their environmental standards and targets that help manage stakeholders and communities' perceptions about their legitimacy. Nguyen (2021) stressed the need to improve institutional performance and uphold the law to improve tourism activities and environmental sustainability. The study considered more than three thousand tourism companies in Vietnam in the year 2018 and found the Ushaped relationship between the rule of law and foreign inbound tourism, underlined the environmental governance framework. The study underscored developing a better governance framework that reduces the conflict between the performance of the local and foreign tourism companies and the rule of law in a country. Kagaya \& Wada (2021) argued that the environmental governance system should be well-organized and problem-solving up to the regional level, leading to its ecological conservation. Watershed management is the important task to control floods, efficient use of water resources, and river management, which is possible when the ecological governance system is tied up with the new environmental standards and sustainability principles. Aguilera et al. (2021) investigated the corporate actions about the environmental sustainability scoring under the environmental governance system that is tied up with the global financial system, regulatory framework, and stakeholders. The corporate governance actors likely achieve ecological sustainability outcomes that make policies under the sustainability principles. Dressel et al. (2021) suggested that the collaborative governance approach is considered a good exemplary case that is valuable to minimize negative environmental externalities. The greater need to design an ecological governance framework should be flexible to utilize institutional factors to move forward towards a social learning process that benefits stakeholder groups. Jiang et al. (2021) concluded that coherent and efficient ecological governing policies support the effectiveness of government policies to improve air quality levels, leading the governing policies transparent, structurally adjusted, and symmetric disclosure of environmental policies. Gök \& Sodhi (2021) collected and analyzed the environmental governance data of 115 countries from 2000 to 2015 and found that high-income countries enjoyed better governance practices that were helpful to improve their air quality indicators. On the other hand, the low- and middle-income countries need to be designed an eco-friendly governance policy to mitigate negative environmental externalities Based on the literature review, the study formulated the following research hypotheses, i.e.,

H1: The green growth agenda is likely to be positively influenced by environmental democracy and shared political wisdom.

H2: Incentive-based regulations and government effectiveness likely to play their roles to achieve environmental sustainability agenda, and

H3: Environmental corruption is likely to influence ecological sustainability ratings, leading to environmental legislation negatively.

The study contributed to the existing literature from different perspectives. First, the study modified world governance indicators to environmental governance indicators using environmental sustainability ratings (used as a response variable in the study) to build an environmental governance framework in a large cross-section of data. Second, the study proposed three different theories related to the environmental governance framework, i.e., Demopolis theory (emphasis on environmental democracy and environmental politics), Effective regulatory theory (emphasis on government effectiveness and environmental regulations), and Theory of law and corruption (emphasis on environmental laws and environmental corruption). Based on the stated theories, the study built an efficient, sustainable governance system and possessed greater good governance indicators across countries. Finally, the study used the country's per capita income as a control variable related to environmental governance indicators and ecologically sustainable ratings, which gives synergy to the governance framework to move forward towards green development. 
Based on the contribution, the study followed the three research questions that related to environmental sustainability, i.e., to what extent environmental democracy and environmental politics influenced ecological sustainability ratings? This question is leading the Demopolis theory that argued that greater environmental democracy would likely improve ecological sustainability ratings while impairs due to political instability. The second research question is about the theory of government effectiveness and environmental regulations, i.e., does government effectiveness and incentive-based environmental regulations increases ecological ratings? The effective regulatory theory contended that government policies and formal \& informal environmental regulations help the world economies to move forward towards green development through contingent evaluation of willingness-to-pay for environmental protection and carbon pricing. Finally, the third research question is: does environmental legislation and environmental corruption move together in the opposite direction against ecological ratings? The stringent environmental laws help reduce dirty pollution, while environmental corruption deteriorates ecological sustainability ratings that need to be stabilized through efficient governance mechanisms to stop the rot.

The stated research questions derive the study's main objectives, which are as follows:

i) To examine the role of environmental democracy and politics in improving ecological sustainability ratings in extensive cross-sectional data.

ii) To assess the role of effective government policies and sound ecological regulations in enhancing green sustainability agenda, and

iii) To investigate the impact of stringent environmental legislations and increasing corruption on environmental sustainability ratings across countries.

Based on the study's contribution, proposed set of research questions, and study objectives, the study moves forward to design an efficient environmental governance framework that encompasses all the important considerations of building any framework for their acceptability. The study achieved the stated objectives by utilizing sophisticated statistical techniques that help to formulate sound sustainability policies across countries.

\section{Data and Methodology}

The study utilized the number of world governance indicators concerning environmental sustainability ratings to form an environment governance indicator, i.e., environmental democracy (denoted by ENVDEM), politics (denoted by ENVPOL), effectiveness (denoted by GOVTEFF), regulations (denoted by ENVREG), laws (denoted by ENVLAW), and environmental corruption (denoted by ENVCOR).
The governance indicators taken from the World Governance database (WGI, 2021) have index values that fall between -2.5 (low governance) to +2.5 (high governance). Further, the data of environmental sustainability rating (denoted by ESR) and GDP per capita (denoted by GDPPC) were taken from the World Bank (2021). The ESR index value contains 1 (low) to 6 (high) sustainability rating data set while GDP per capita is in constant 2010 US\$. The crosssectional data of 67 countries were used in the analysis for 2019. Table 1 in the appendix shows the list of countries for ready reference.

\subsection{Theoretical Underpinning}

The study makes sure the following theoretical considerations before designing the environmental governance framework.

i) The framework covered all essential aspects of human development, including political aspects, social, and economic aspects.

ii) Government, business entities, and civil society get equally benefited from the green reforms.

iii) The suggested framework is broad and flexible, and it contains all aspects of public goods.

iv) The environment and resource conservation agenda is considered a priority and in line with international standards.

v) The command-and-control mechanism is introduced that is fair and easily applicable to all segments of society.

vi) Environmental justice, equity, and sustainability are covered in the governance framework, leading to sharing at all levels.

vii) Greater transparency, access to resources, and freedom of voice are used as governing factors in this framework.

viii) Political reforms, capacity building, and policy integration are the key determinants of the governance system.

ix) Well-defined policies, institutional reforms, and practical implications are linked with the framework.

x) Legislative reforms, technical collaboration and innovation are suggested as a part of the governance framework.

xi) Regulatory control, business disclosure, and management process streamline with the framework.

xii) Structural forces, cultural beliefs, and political ecology are considered for the governance framework.

xiii) Private property rights allow owners to manage resources better and link them with the market incentives that help design the governance framework.

xiv) Environmental laws are applied in order to implement environmental policies forcefully for fulfilling the need of future generations, and 


\begin{tabular}{|c|c|c|}
\hline Environmental Standards & Access to Information & $\begin{array}{l}\text { Environmental Social } \\
\text { Movements }\end{array}$ \\
\hline $\begin{array}{l}\text { - Protecting land and natural } \\
\text { resources } \\
\text { - Maintaining equity }\end{array}$ & $\begin{array}{l}\text { - Information about } \\
\text { environmental hazards } \\
\text { - Access to information } \\
\text { about healthcare } \\
\text { sustainability }\end{array}$ & $\begin{array}{l}\text { - Conservation } \\
\text { - Preservation }\end{array}$ \\
\hline
\end{tabular}

Figure 2. Structure of Demopolis Theory in Environmental Sustainability, source: Authors extract
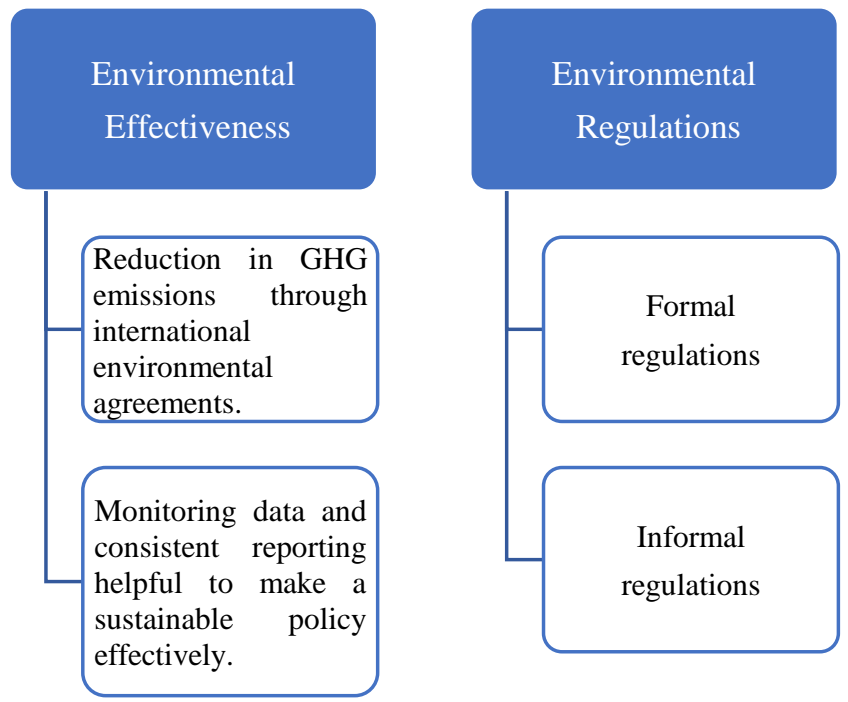

Figure 3. Effective Regulatory Theory, source: Self-extract

xv) Cross-scale governance is applied at the core of the environmental governance framework.

The stated fifteen points are ensured while preparing the environmental governance framework. The study gets benefited from the recent scholarly work of Partelow et al. (2020) and extended their eight suggested theoretical considerations for evaluating environmental governance theory into the three different theories and developed a more pragmatic and flexible governance framework for green development, i.e.

I) Demopolis Theory: The Demopolis theory emphasizes freedom of expression, freedom of voice, and accountability that remains feasible in the country's political structure to correspond to the governance system. The symmetric information is liable when the country has a more significant social interaction with the stakeholders, directly or indirectly associated with the economic and environmental problems (Wang et al., 2020). The study utilized Demopolis theory to achieve the environmental sustainability agenda by using democracy and politics that remain helpful to improve sustainability ratings. Figure 2 shows the Demopolis theory in the green developmental agenda to move toward sustainable production and consumption.

Figure 2 shows that Demopolis theory stands out of three essential elements. First, it discusses how to maintain ecological standards that are helpful to protect land and natural resources on an equitable basis. Second, it discussed the rights to get information about environmental destructions and healthcare externalities, leading to legislation for damagesfinally, the environmental social movements leading the environmental politics towards resource conservation and preservation for the future generation.

II) Effective Regulatory Theory: The Effective Regulatory theory greatly emphasized the need to devise stringent environmental reforms to reduce dirty production. The stated theory linked government effectiveness with ecological regulations to monitor environmen- 


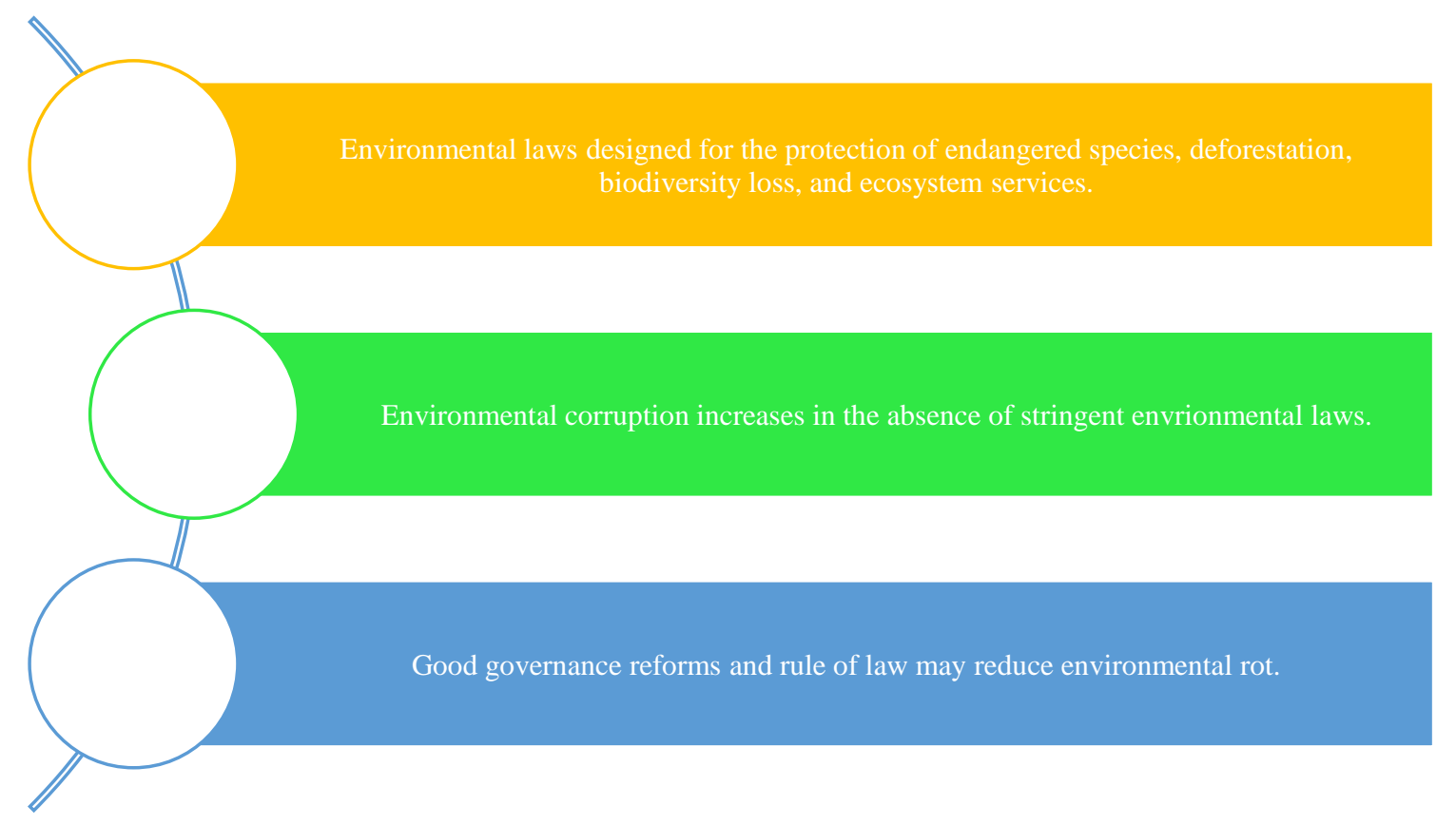

Figure 4. Theory of Environmental Laws and Corruption, source: Self-extract

tal and healthcare damages and moving towards a solid regulatory policy to combat the environmental evils, which deteriorating healthcare sustainability agenda. The incentive-based model to improve environmental quality always remains debatable in eco-centric theories, which remains a need to reach some conclusive remarks (Pasgaard et al., 2017). Technological development (Zhang et al., 2018), renewable fuels (Le \& Sarkodie, 2020), cleaner production techniques (Giannetti et al., 2020), and carbon pricing (Anser et al., 2021) remains used in environmental regulations to subside the negative environmental externalities. Figure 3 shows the main elements of effective regulatory theory for ready reference.

Figure 3 shows that reliable data and reporting are helpful to devise green policies to mitigate GHG emissions effectively. Formal environmental regulations help to reduce negative environmental externalities through carbon taxes and emissions-cap trading (Zaman et al., 2021). The emerging awareness of environmentally friendly products leading the informal regulations to publicize information about environmental damages (Ramzan et al., 2019). The contingent evaluation technique can formally devise green policies based on willingness to accept or pay for environmental protection (Gupta \& Chatterjee, 2021). The green outcomes would be improving environmental ratings, air quality levels, and improving healthcare status worldwide.

III) Theory of Law and Corruption: The theory of law and corruption comprises environmental laws and corruption. Environmental laws were designed to reduce environmental corruption (Williams \& Dupuy, 2017). The protection of environmental and natural resources is essential to move forwards to attain the United Nations sustainable development goals till 2030 (Qureshi et al., 2019). Pollution control laws, waste management, and cleanup costs all are associated with environmental laws (Rajmohan et al., 2019). The formal and informal environmental regulations align international environmental protection agencies to green policies (Coenen et al., 2021). Environmental corruption limits sustainable policies and economic agendas, fueling poverty, criminality, and biodiversity loss (Tacconi \& Williams, 2020). The greater need to strengthen the governance reforms and international enforcement to reduce environmental corruption is vital for healthy well-being. Figure 4 shows the main possible elements of the theory of environmental laws and corruption for ready reference.

Based on the theoretical underpinning of the literature, the study formulated the environmental governance model, where environmental sustainability rating influenced the governance factors and the country's economic growth, i.e. 


$$
\begin{aligned}
& E S R_{67,2019}=\delta_{0}+\delta_{1} \text { ENVDEM }_{67,2019}+\delta_{2} E_{N V P O L_{67,2019}}+\delta_{3} G_{\text {OVTEFF }}{ }_{67,2019}+\delta_{4} E N V R E G_{67,2019} \\
& +\delta_{5} E N V L A W_{67,2019}+\delta_{6} E N V C O R_{67,2019}+\delta_{7} G D P P C_{67,2019}+\varepsilon_{67,2019} \\
& \therefore \frac{\partial(E S R)}{\partial(E N V D E M)}>0, \frac{\partial(E S R)}{\partial(E N V P O L)}<0, \frac{\partial(E S R)}{\partial(G O V T E F F)}>0, \frac{\partial(E S R)}{\partial(E N V R E G)}>0, \frac{\partial(E S R)}{\partial(E N V L A W)}>0 \text {, } \\
& \frac{\partial(E S R)}{\partial(E N V C O R)}<0
\end{aligned}
$$

where ESR shows environmental sustainability rating, ENVDEM shows environmental democracy, ENVPOL shows environmental politics, GOVTEFF shows government effectiveness, ENVREG shows environmental regulations, ENVLAW shows environmental laws, ENVCOR shows environmental corruption, GDPPC shows GDP per capita, and $\varepsilon$ shows error term.

Equation (1) shows that environmental democracy, government effectiveness, environmental regulations, and environmental laws are likely to influence environmental sustainability ratings positively. In contrast, environmental politics and environmental corruption are likely to affect sustainability ratings across countries negatively. Figure 5 shows the environmental governance framework for ready reference.

\subsection{Econometric Framework}

Based on the theoretical literature and supported argument to build an environmental governance framework, equation (1) is empirically estimated by the switching regression approach. Further, the causal inferences have been drawn based on Granger causality estimates. Finally, the forecasted relationship has been analyzed through variance decomposition analysis (VDA). Qnadt (1972) first derived the regime-based switching regression model that overcomes the mixture of generalized distributions in the regression. The sample is segregated based on either known or unknown sample separation. The a priori information about sample segregation in the underlying regimes leading to the known sample segregation; otherwise, it would lead to unknown sample segregation. The current study has some sample information, but this information is not enough to fall in the known sample separation; hence we used unknown sample separation in the two different regimes. The classical switching regression model is presented here that elaborated the equation (1) into two different equations, which includes regime-1 and regime- 2 equations and standard equation, i.e.,

- Regime-1 \& 2 equations:

ESR $_{67,2019}=\delta_{0}+\delta_{1}$ ENVDEM $_{67,2019}+\delta_{2}$ ENVPOL $_{67,2019}$

$+\delta_{3}$ ENVREG $_{67,2019}+\delta_{4}$ ENVLAW $_{67,2019}$

$+\delta_{5}$ ENVCOR $_{67,2019}+\varepsilon_{67,2019}$

- Common equation:

$$
\operatorname{ESR}_{67,2019}=\delta_{0}+\delta_{1} \text { GOVTEFE }_{67,2019}
$$

$$
+\delta_{2} G D P P C_{67,2019}+\varepsilon_{67,2019}
$$

By combining equations (I) and (II), the switching regression equations become similar to the equation (1) as presented earlier.

After estimating equation (1), the study moves forward to estimate cause-effect relationships between the governance indicators and environmental sustainability rating. The Granger causality test is applied on the cross-sectional data set and deduce the four possible causation between the stated variables, i.e.

Case I: One-way causation running from governance indicators to environmental sustainability rating, i.e.

- Demopolis Factors:

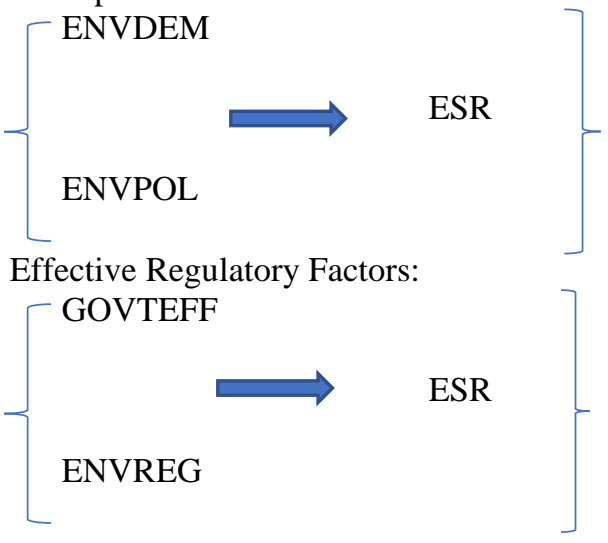

- Environmental Laws and Corruption Factors:

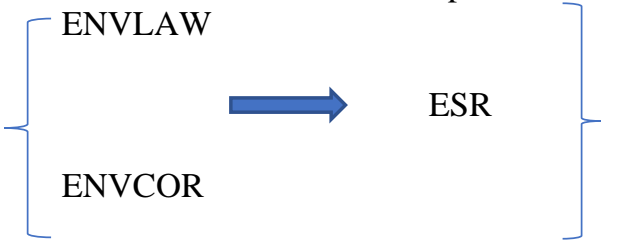

Case II: Reverse causation running from environmental sustainability rating to governance indicators, i.e.

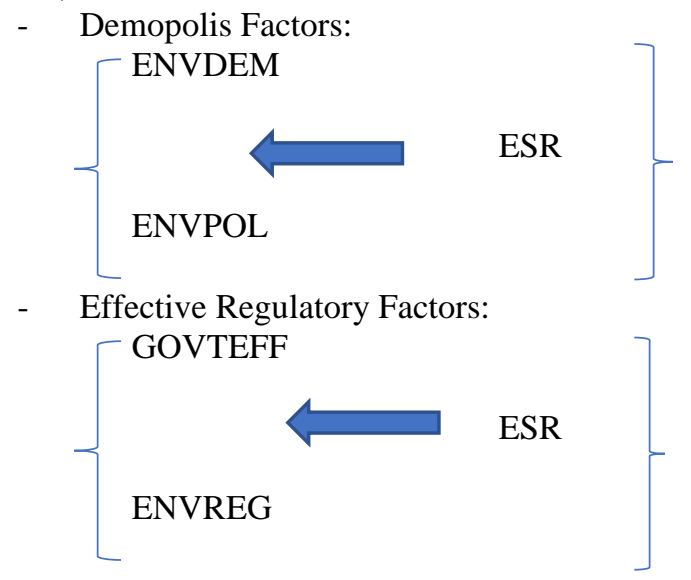


- Environmental Laws and Corruption Factors:

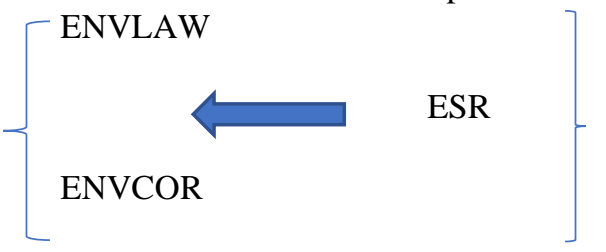

Case III: Two-way causation between governance indicators and environmental sustainability rating, i.e.

- Demopolis Factors:

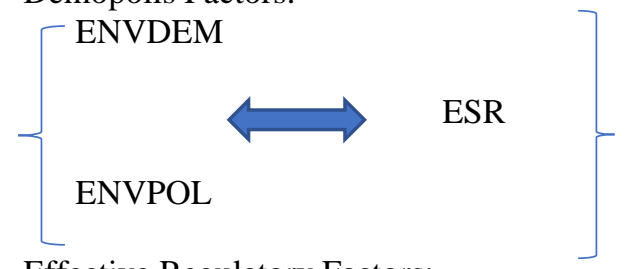

- Effective Regulatory Factors:

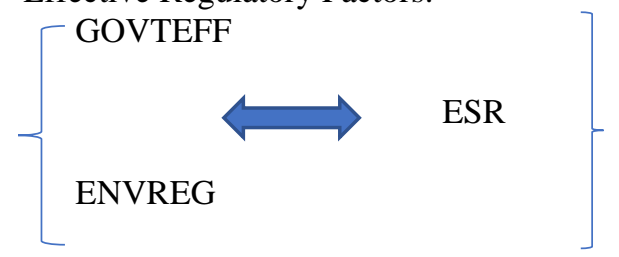

- Environmental Laws and Corruption Factors:

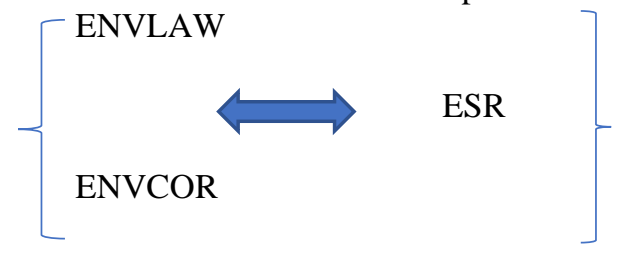

Finally, Case IV: No causation between governance indicators and environmental sustainability rating, although highly correlated, i.e.,

- Demopolis Factors:

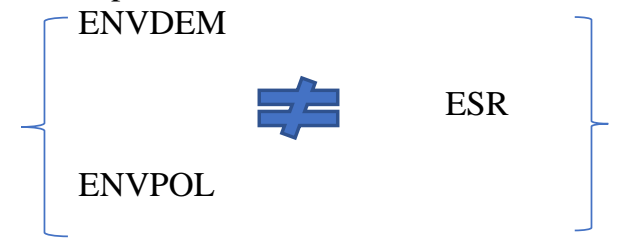

- Effective Regulatory Factors:

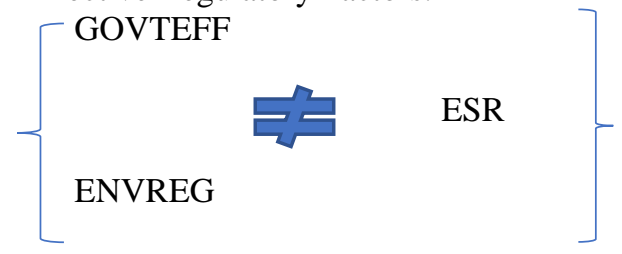

- Environmental Laws and Corruption Factors:

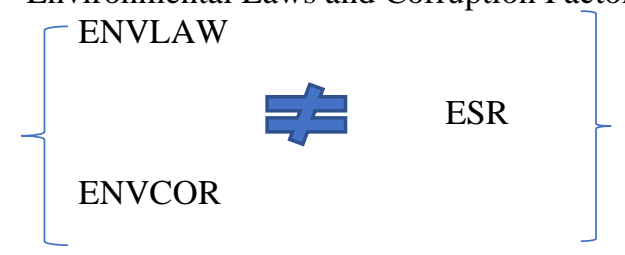

After estimating the causal inferences, the study analyzed the forecast estimates between the governance and environmental suitability ratings through the VDA approach. The variation between the gov- ernance factors that influenced the sustainability rating can be accessed over a time horizon. The study forecasted the estimates for the next ten years' time period and observed the greater magnitude to influence governance factors to sustainability rating. The VDA estimates were calculated based on vector autoregression (VAR) modelling in a multivariate framework. Equation (1) can be decomposed into VAR framework to understand the VDA approach, i.e.,

$\operatorname{Var}(E S R)=E(\operatorname{Var}[E S R /$ Environmental Governance Factors $]+\operatorname{Var}(E[E S R / E n v i r o n m e n t a l$ Governance Factors]

Where,

$\mathrm{E}$ (Var[ESR/Environmental Governance Factors] = explained variation in the account of changes in the environmental governance factors,

while

Var(E[ESR/Environmental Governance Factors] = unexplained variation in the account of other random factors other than the governance factors.

The VDA estimates show the fluctuations in the sustainability rating explained by the innovation of the governance indicators.

\section{Results and Discussion}

Table 1 shows the descriptive statistics of the variables. The average value of environmental governance indicators are mainly with a negative sign, i.e., environmental corruption, democracy, law, and environmental politics have negative values of -0.071 , $-0.063,-0.024$, and -0.055 , respectively, while environmental regulations and government effectiveness have a positive mean value of 0.062 and 0.019 , respectively. The minimum value of the environmental sustainability rating is 2 , while the maximum value is 4.5 , with an average value of 3.291 . The stated variable is negatively skewed and high kurtosis value. The mean value of per capita income is US $\$ 2320.357$. The negative trended values of the selected governance indicators show that environmental sustainability rating would be going down, leading the economies towards unsustainable production and consumption. The environmental governance mechanism should be transparent and equitable, helps to move towards global prosperity.

Table 2 shows that environmental governance indicators positively correlated with the environmental sustainability rating; however, environmental corruption, democracy, laws, and regulations negatively correlated with the country's economic growth, which remains the question of achieving global prosperity. Government effectiveness is the policy variable that is positively correlated with the rest of the governance indicators. Environmental law improves democracy while it increases environmental regulations and government effectiveness - the need for improving governance indicators is key to moving forward towards environmental sustainability. 


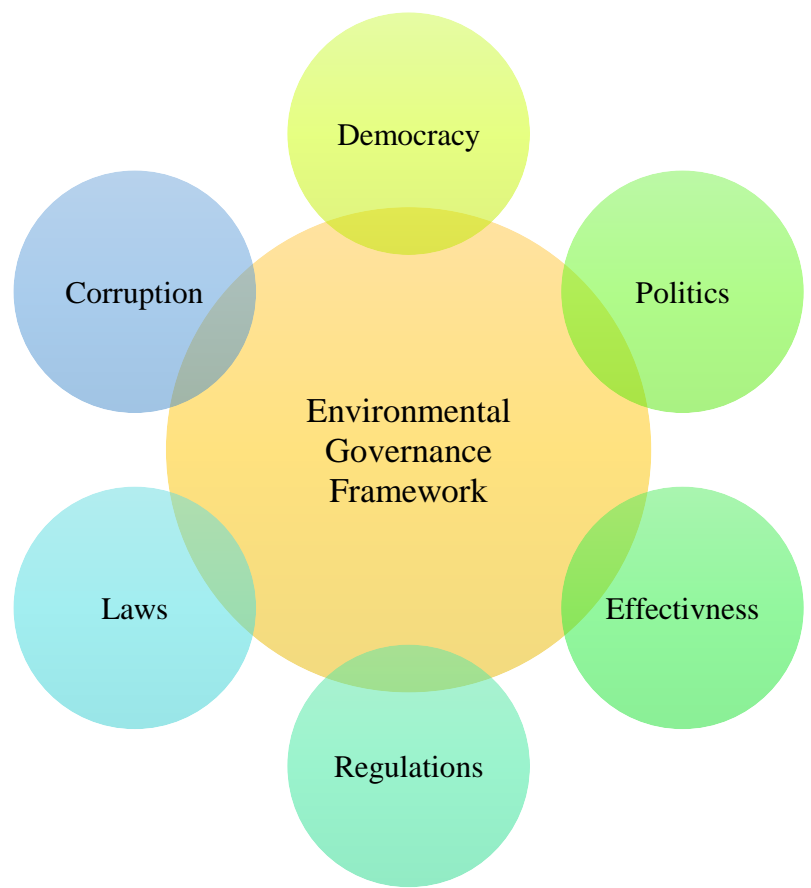

Figure 5. Environmental Governance Framework, source: Self Extract

Table 1. Descriptive Statistics

\begin{tabular}{|l|c|c|c|c|c|c|c|c|}
\hline Methods & ENVCOR & ENVDEM & ENVLAW & ENVPOL & ENVREG & ESR & GOVTEFF & GDPPC \\
\hline Mean & -0.071 & -0.063 & -0.024 & -0.055 & 0.062 & 3.291 & 0.019 & 2320.357 \\
\hline Maximum & 2.159 & 1.524 & 1.878 & 1.627 & 2.161 & 4.500 & 2.221 & 9350.748 \\
\hline Minimum & -1.773 & -1.974 & -1.969 & -2.558 & -2.048 & 2 & -2.451 & 208.074 \\
\hline Std. Dev. & 0.962 & 0.943 & 0.930 & 0.891 & 0.887 & 0.523 & 0.942 & 2201.947 \\
\hline Skewness & 0.639 & -0.254 & 0.389 & -0.372 & 0.384 & -0.458 & 0.197 & 1.731 \\
\hline Kurtosis & 2.655 & 2.069 & 2.217 & 3.020 & 2.597 & 3.186 & 2.647 & 5.326 \\
\hline
\end{tabular}

Note: ENVCOR shows environmental corruption, ENVDEM shows environmental democracy, ENVLAW shows environmental laws, ENVPOL shows environmental politics, ENVREG shows environmental regulations, ESR shows environmental sustainability rating, GOVTEFF shows government effectiveness, and GDPPC shows GDP per capita.

Table 3 shows the switching regression estimates and found that in regime-1, environmental corruption has a negative relationship with the environmental sustainability rating scale. In contrast, environmental democracy and environmental politics are positively associated with sustainability, leading the economy towards pragmatic and viable policy options. In regime-2, environmental democracy was positively affected, while environmental politics and laws negatively affected environmental sustainability ratings across countries. Government effectiveness and the country's per capita income increases environmental sustainability ratings, leading towards green and clean development. The results align with the earlier studies, which confirmed that environmental governance indicators improve sustainability rating to move forward towards attaining green growth agenda (Rajesh \&Rajendran, 2020; Sun et al., 2020; Rajesh, 2020). Leal \& Marques (2021) argued that economic globalization allows dirty polluting industries to set up their production plants into less regulated environmental economies to gain economic profit. Moreover, political globalization improves environmental quality by imposing stringent environmental regulations to clear out the dirty industries. Environmental corruption and polluting industries can be restricted through incentivebased sustainable regulations. Ganda (2020) concluded that environmental corruption damaged the sustainability rating index, which needs to be limited through stringent environmental laws and regulations. Arminen \& Menegaki (2019) found that climate and weather variations and corruption increases energy demand and carbon emissions, leading the global world into economic depression.

The results show that environmental democracy positively influenced the environmental sustainability rating in both regime- 1 and regime- 2 . The result implies that freedom of expression to spread environmental views improves environmental quality to conserve ecological resources for future generations. Pickering et al. (2020) showed different challenges that democracy faced implementing the ecological conservation process, including the low level of public participation for willingness-to-pay for the environment, lack of expertise, governance issues, and limited ecological rights. These challenges are slowing down the governance process of improving envi- 
Table 2. Correlation Matrix

Correlation

\begin{tabular}{|c|c|c|c|c|c|c|c|c|}
\hline \multirow{3}{*}{$\begin{array}{l}\text { Probability } \\
\text { ENVCOR } \\
\end{array}$} & ENVCOR & ENVDEM & ENVLAW & ENVPOL & ENVREG & ESR & GOVTEFF & GDPPC \\
\hline & 1 & & & & & & & \\
\hline & ----- | & & & & & & & \\
\hline & & & & & & & & \\
\hline ENVDEM & 0.757 & 1 & & & & & & \\
\hline & 0.000 & ----- & & & & & & \\
\hline & & & & & & & & \\
\hline ENVLAW & 0.937 & 0.762 & 1 & & & & & \\
\hline & 0.000 & 0.000 & ----- & & & & & \\
\hline & & & & & & & & \\
\hline ENVPOL & 0.705 & 0.660 & 0.758 & 1 & & & & \\
\hline & 0.000 & 0.000 & 0.000 & ----- & & & & \\
\hline & & & & & & & & \\
\hline ENVREG & 0.893 & 0.701 & 0.911 & 0.651 & 1 & & & \\
\hline & 0.000 & 0.000 & 0.000 & 0.000 & ----- & & & \\
\hline & & & & & & & & \\
\hline ESR & 0.412 & 0.391 & 0.400 & 0.345 & 0.455 & 1 & & \\
\hline & 0.000 & 0.001 & 0.000 & 0.004 & 0.000 & ---- & & \\
\hline GOVTEFF & 0.913 & 0.661 & 0.935 & 0.728 & 0.940 & 0.435 & 1 & \\
\hline & 0.000 & 0.000 & 0.000 & 0.000 & 0.000 & 0.000 & ---- & \\
\hline & & & & & & & & \\
\hline GDPPC & -0.099 & -0.043 & -0.089 & 0.019 & -0.057 & 0.180 & -0.107 & 1 \\
\hline & 0.423 & 0.726 & 0.473 & 0.876 & 0.645 & 0.144 & 0.385 & ----- \\
\hline
\end{tabular}

Note: ENVCOR shows environmental corruption, ENVDEM shows environmental democracy, ENVLAW shows environmental laws, ENVPOL shows environmental politics, ENVREG shows environmental regulations, ESR shows environmental sustainability rating, GOVTEFF shows government effectiveness, and GDPPC shows GDP per capita.

Table 3. Switching Regression Estimates

\begin{tabular}{|c|c|c|c|c|}
\hline \multicolumn{5}{|c|}{ Dependent Variable: ESR } \\
\hline Variable & Coefficient & Std. Error & z-Statistic & Prob. \\
\hline C & 2.979 & 0.093 & 31.708 & 0.000 \\
\hline ENVCOR & -1.167 & 0.278 & -4.196 & 0.000 \\
\hline ENVDEM & 0.263 & 0.128 & 2.042 & 0.041 \\
\hline ENVLAW & 0.404 & 0.283 & 1.428 & 0.153 \\
\hline ENVPOL & 0.473 & 0.106 & 4.451 & 0.000 \\
\hline ENVREG & -0.238 & 0.233 & -1.021 & 0.307 \\
\hline \multicolumn{5}{|c|}{ Regime 2 } \\
\hline C & 3.123 & 0.076 & 41.047 & 0.000 \\
\hline ENVCOR & 0.235 & 0.200 & 1.177 & 0.238 \\
\hline ENVDEM & 0.416 & 0.136 & 3.044 & 0.002 \\
\hline ENVLAW & -0.701 & 0.275 & -2.549 & 0.010 \\
\hline ENVPOL & -0.521 & 0.151 & -3.432 & 0.000 \\
\hline ENVREG & -0.109 & 0.198 & -0.550 & 0.582 \\
\hline \multicolumn{5}{|c|}{ Common } \\
\hline GOVTEFF & 0.838 & 0.219 & 3.812 & 0.000 \\
\hline GDPPC & $8.34 E-05$ & $2.16 \mathrm{E}-05$ & 3.870 & 0.000 \\
\hline LOG(SIGMA) & -1.297 & 0.125 & -10.360 & 0.000 \\
\hline \multicolumn{7}{|c|}{ Probabilities Parameters } \\
\hline Mean dependent var & -0.280 & 0.408861 & -0.687195 & 0.4920 \\
\hline S.E. of regression & 3.291 & S.D. dependent var & 0.523 \\
\hline Durbin-Watson stat & 1.961 & Sum squared resid & 15.232 \\
\hline Hanaike info criterion & 1.425 & \multicolumn{2}{|c|}{ Schwarz criterion } & 1.951 \\
\hline
\end{tabular}

Note: ENVCOR shows environmental corruption, ENVDEM shows environmental democracy, ENVLAW shows environmental laws, ENVPOL shows environmental politics, ENVREG shows environmental regulations, ESR shows environmental sustainability rating, GOVTEFF shows government effectiveness, and GDPPC shows GDP per capita. 
Table 4. Diagnostic Tests

\begin{tabular}{|c|c|c|c|}
\hline Tests & Values & Prob. Value & Remarks \\
\hline Jarque-Bera Test & 0.657 & 0.719 & Residual is normally distributed \\
\hline $\begin{array}{c}\text { Breusch-Godfrey Serial } \\
\text { Correlation LM Test }\end{array}$ & 1.499 & 0.231 & Free from autocorrelation problem \\
\hline $\begin{array}{c}\text { Breusch-Pagan-Godfrey } \\
\text { Heteroskedasticity Test }\end{array}$ & 0.889 & 0.520 & Homoscedastic \\
\hline Ramsey RESET Test & 0.398 & 0.691 & Model is stable \\
\hline
\end{tabular}
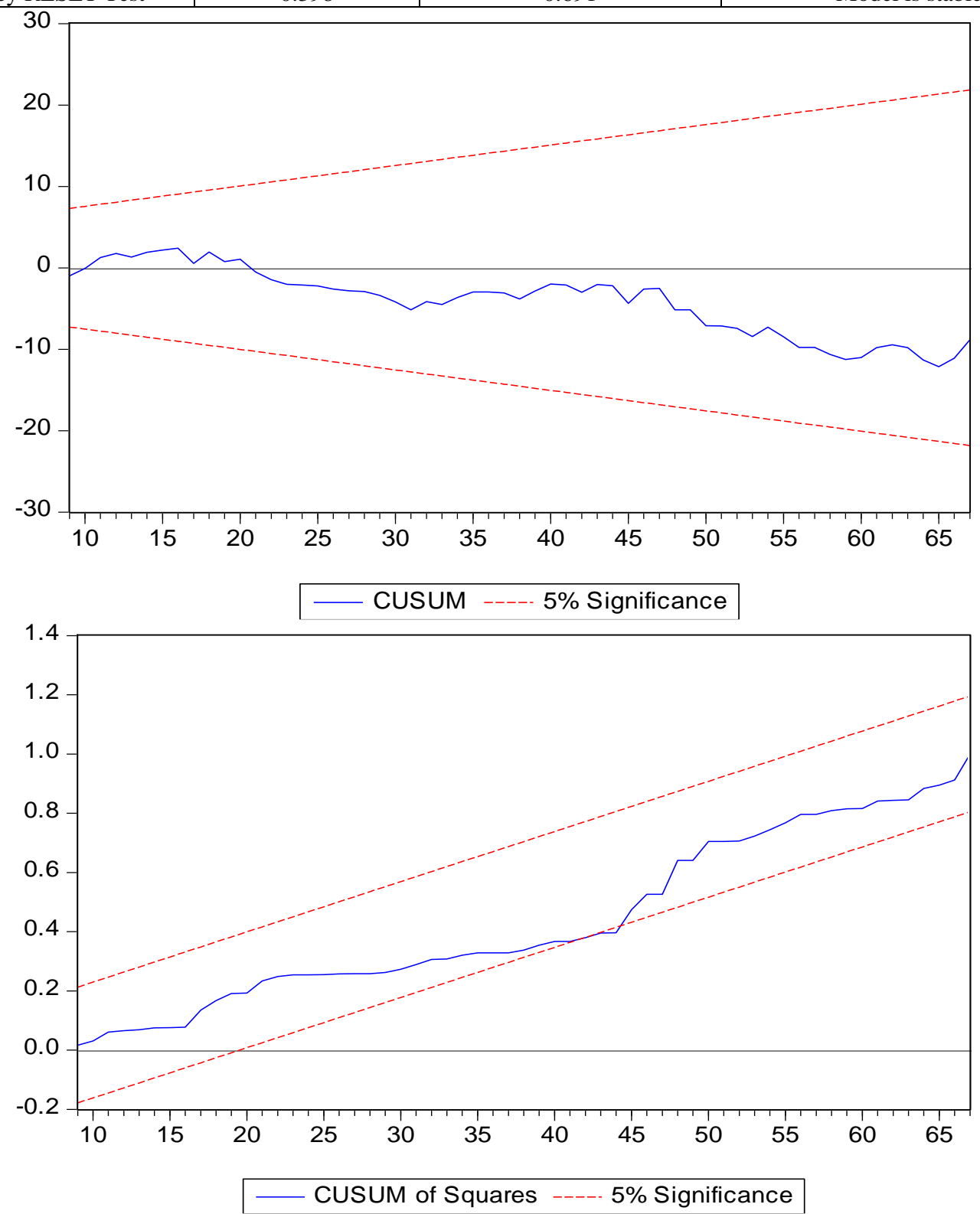

Figure 6. CUSUM and CUSUM Square Test, source: Authors estimation

ronmental quality. Haseeb \& Azam (2021) found that corruption and democracy have a differential impact on carbon emissions. The former deteriorates the environment while later improves environmental quality, leading the economies toward more pragmatic solutions to stop the rot and improve democracy betterment of the future generation. Usman et al. (2020) argued that democracy is helpful to improve air quality levels and reduces negative environmental externalities.
The negative relationship found between environmental laws, politics, and ecological suitability rating in regime- 2 apparatus implies that the imposition of stringent laws for the betterment of the environment leading deterioration in the sustainability ratings because of a higher level of environmental politics. Asongu \& Odhiambo (2020) suggested that governance indicators need to be improved to tackle negative environmental externalities. Barbosa et al. (2021) confirmed the viability of imposing stringent 
Table 5. Granger Causality Estimates

\begin{tabular}{|c|c|c|c|}
\hline \multicolumn{2}{|l|}{ Unidirectional Causality } & \multicolumn{2}{|l|}{ Bidirectional Causality } \\
\hline Causal Factors & F-statistics & Causal Factors & F-statistics \\
\hline ENVCOR $\rightarrow$ ENVPOL & $\begin{array}{l}2.698 \\
(0.075)\end{array}$ & \multirow[t]{2}{*}{ ENVREG $\leftrightarrow$ ENVCOR } & $\begin{array}{l}3.199 \\
(0.047)\end{array}$ \\
\hline GOVTEFF $\rightarrow$ ENVCOR & $\begin{array}{l}2.602 \\
(0.082)\end{array}$ & & $\begin{array}{l}3.072 \\
(0.053)\end{array}$ \\
\hline $\mathrm{ENVCOR} \rightarrow \mathrm{GDPPC}$ & $\begin{array}{l}3.500 \\
(0.036)\end{array}$ & \multirow[t]{2}{*}{ ENVREG↔ENVPOL } & $\begin{array}{l}5.673 \\
(0.005) \\
\end{array}$ \\
\hline ENVDEM $\rightarrow$ GDPPC & $\begin{array}{l}4.710 \\
(0.012)\end{array}$ & & $\begin{array}{l}2.519 \\
(0.089) \\
\end{array}$ \\
\hline ENVLAW $\rightarrow$ ENVPOL & $\begin{array}{l}4.692 \\
(0.012)\end{array}$ & \multirow{5}{*}{\multicolumn{2}{|c|}{$\begin{array}{l}\text { Note: ENVCOR shows environmental corruption, ENVDEM } \\
\text { shows environmental democracy, ENVLAW shows environ- } \\
\text { mental laws, ENVPOL shows environmental politics, EN- } \\
\text { VREG shows environmental regulations, GOVTEFF shows } \\
\text { government effectiveness, and GDPPC shows GDP per cap- } \\
\text { ita. The small bracket shows the probability value. }\end{array}$}} \\
\hline ENVLAW $\rightarrow$ GDPPC & $\begin{array}{l}4.064 \\
(0.022)\end{array}$ & & \\
\hline GOVTEFF $\rightarrow$ ENVPOL & $\begin{array}{l}6.563 \\
(0.002)\end{array}$ & & \\
\hline $\mathrm{ENVREG} \rightarrow \mathrm{GDPPC}$ & $\begin{array}{l}3.384 \\
(0.040)\end{array}$ & & \\
\hline GOVTEFF $\rightarrow$ GDPPC & $\begin{array}{l}3.067 \\
(0.053)\end{array}$ & & \\
\hline
\end{tabular}

environmental laws to improve environmental quality. In the absence of environmental laws, the impact of environmental quality negatively affected human well-being and biodiversity loss. Hence, it is crucial to move forward to improve ecological standards through devising sustainable laws for resource conservation. Murshed et al. (2021) concluded that ecological footprints could be limited by imposing stringent regulations coupled with renewable energy that help move forward towards global prosperity.

The per capita income and government effectiveness played an essential role in improving environmental sustainability ratings, as continued economic growth and government efficient policies helpful to build solid institutional support that takes care of environmental resources and way forwards towards shared prosperity. Adekunle (2020) argued that governance factors are helpful to determine the role of environmental resources in attaining ecological sustainability. The regulatory quality and the rule of law are headed to transform the green development agenda through good governance reforms. The government effectiveness needs more caution to improve environmental quality to enhance institutional performance. Khan et al. (2021) concluded that sound institutional quality is helpful to draw a positive image of the country to the way forward towards attaining ecological sustainability, leading to improve regulatory bodies and utilizing a green energy mix that enables the world to progress for green growth agenda. Kamah et al. (2021) found that institutional quality intervenes in the growth-sustainability nexus to decrease environmental damages and support inclusive growth agendas. Table 4 shows the diagnostic testing estimates of the regression apparatus.

The results show that the Jarque-Bera statistics (used for assessing the normality of the residuals) are statistically insignificant; hence it accepted the null hypothesis that the residual of the regression estimates is normally distributed. Further, the study used a serial correlation test and confirmed that the regression estimates have no such autocorrelation problem; hence the result is generally consistent and unbiased. The heteroskedasticity test is also in line with the other diagnostic estimates and confirmed that the residual of the regression estimates has constant variance. Finally, the model stability is checked by the Ramsey RESET test and confirmed that the model estimates are stable over time. Figure 6 shows the CUSUM and CUSUM square estimates for ready reference.

The CUSUM and CUSUM square test confirmed that the model is statistically significant at a $5 \%$ level; hence the given regression estimates are stable in the long run. Table 5 shows the Granger causality estimates and found that environmental corruption Granger causes ecological politics and per capita income, whereas environmental law and government effectiveness both Granger cause to environmental politics and economic growth. Further, government effectiveness Granger causes environmental corruption, while environmental democracy and environmental regulations Granger cause economic growth. Environmental regulation has a two-way linkage with environmental corruption, and environmental politics to support regulation led corruption and politics across countries. Based on the causal estimates, the study further moves to estimate forecasted variance decomposition error of environmental sustainability rating influenced by the environmental governance indicators.

The stability of the VAR model is essential before going to estimate variance decomposition analysis. The model stability can be checked by the inverse roots of AR characteristics polynomial. The AR inverse roots should be less than the unity, corresponding that the polynomial values remain inside the unit circle. Figure 7 clearly shows that the VAR model is 
stable as the inverse roots of AR polynomial characteristics remain inside the circle and value less than the unity. Hence, the study safely moves to the estimates VDA model.

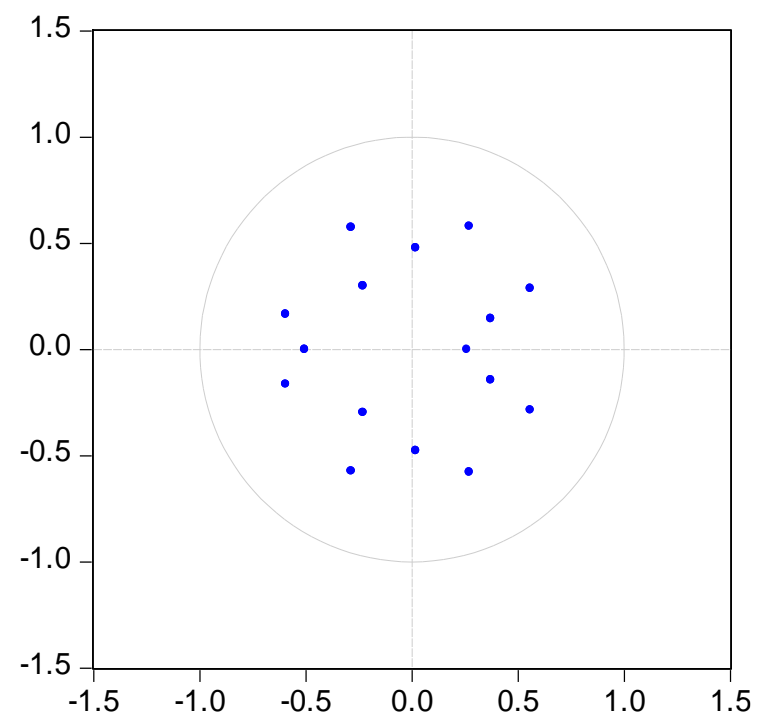

Figure 7. VAR Stability Test, source: Authors estimates

Table 6 shows the VDA estimates of ESR, indicating that shock to ESR account is $100 \%$ and $70.498 \%$ variability in itself in the first and tenth periods, respectively, which found a downward trend over the time horizon. Further, variability in the ESR from $0 \%$ to $2.533 \%$ can be explained by the innovation to corruption indicator, showing an increasing trend over the next ten years' time period. The other governance indicators, including environmental democracy, laws, politics, regulation, and government effectiveness, explained their innovation to ESR from $0 \%$ to $4.404 \%, 1.716 \%, 8.844 \%, 1.800 \%$, and $8,657 \%$, respectively. The per capita income explained their innovation on ESR from $0 \%$ to $1.545 \%$ over the time horizon.

The results further suggested that environmental politics will greatly influence ESR, followed by government effectiveness and environmental democracy, whereas the least influenced will be of per capita income on ESR over time. The results emphasized the need to propose sustainable policy implications to support the green developmental agenda across countries.

\section{Conclusions and Policy Implications}

The environmental governance framework comprises socioeconomic and political considerations related to sustainable development, which helps to reduce environmental corruption and promote laws, regulations, and fair politics to achieve a clean and green developmental agenda. This study offered a sustainable governance design to support government effectiveness indicators that help to improve environmental sustainability ratings in a cross-sectional panel of 67 countries. The results show that environmental corruption, stringent environmental laws and environmental politics are the vital detrimental factors of the sustainability agenda that sabotaged the dream of fair economic and environmental resources. The causality estimates confirmed the corruption led economic growth, government effectiveness led political stability, democracy led economic growth, and environmental laws led politics across countries. Further, the two-way linkages between environmental regulations, corruption, and politics open new avenues of sustainability debate, leading the economy to be more vibrant and pragmatic in broad-based development. The forecasting estimates suggested that environmental politics, government effectiveness, and democracy would likely influence environmental sustainability rating for the next ten years. Based on the findings, the study proposed the following policy implications for making an efficient environmental governance framework worldwide, i.e.

i) The cost of environmental corruption impairs economic and environmental resources. The lack of governance framework and ease of environmental policies leading the situation more worsen. The need to set up an anti-corruption unit, strengthen governance framework, harness environmental knowledge, and improve leadership qualities may minimize the stem of corruption worldwide.

ii) The causes of environmental corruption are many, including inadequate transparency mechanism, distorted environmental policies, and political instability leading to more injudicious resource distribution that creates many social evils. The absenteeism of environmental laws and regulations further put pressure on the natural environment that negatively affects the countries' health and wealth. The need for a transparent mechanism for conserving natural resources and stringent government regulations may be helpful to achieve green sustainability agenda.

iii) Environmental democracy is the sustainable policy option to revitalize economic and natural resource policies to equitably address the resource constraints and set a standard for meeting future generation needs. The right to information, equal participation and access to justice are the main ingredients of democracy used to prevent environmental resources. The Rio Declaration is mainly emphasized to access justice to reach the natural resource market to move forward towards a healthy environment. Public participation is imperative for sustainable development. Technocracy may allow ecological rights to limit environmental corruption. 
Table 6. Variance Decomposition Analysis of ESR

\begin{tabular}{|c|c|c|c|c|c|c|c|c|c|}
\hline Period & S.E. & ESR & ENVCOR & ENVDEM & ENVLAW & ENVPOL & ENVREG & GDPPC & GOVTEFF \\
\hline 1 & 0.513090 & 100 & 0 & 0 & 0 & 0 & 0 & 0 & 0 \\
\hline 2 & 0.571078 & 81.23694 & 0.661115 & 1.978861 & 0.224227 & 6.913550 & 1.141690 & 0.201169 & 7.642446 \\
\hline 3 & 0.589529 & 76.42874 & 0.727542 & 1.857895 & 0.600333 & 9.627328 & 1.296293 & 1.491724 & 7.970141 \\
\hline 4 & 0.607248 & 72.36996 & 2.505920 & 4.127292 & 0.773061 & 9.091139 & 1.257067 & 1.454434 & 8.421128 \\
\hline 5 & 0.615466 & 71.55775 & 2.441952 & 4.270633 & 1.411975 & 8.871668 & 1.348676 & 1.424033 & 8.673311 \\
\hline 6 & 0.619353 & 70.77850 & 2.539362 & 4.386761 & 1.549510 & 8.877238 & 1.782131 & 1.500061 & 8.586432 \\
\hline 7 & 0.620158 & 70.61555 & 2.532828 & 4.408625 & 1.638455 & 8.854890 & 1.778515 & 1.537606 & 8.633526 \\
\hline 8 & 0.620734 & 70.52213 & 2.528741 & 4.401808 & 1.714441 & 8.842957 & 1.797102 & 1.540091 & 8.652727 \\
\hline 9 & 0.620805 & 70.50607 & 2.532588 & 4.400996 & 1.716176 & 8.844541 & 1.800194 & 1.544916 & 8.654517 \\
\hline 10 & 0.620843 & 70.49813 & 2.533942 & 4.404034 & 1.716086 & 8.844550 & 1.800116 & 1.545683 & 8.657455 \\
\hline
\end{tabular}

Note: ENVCOR shows environmental corruption, ENVDEM shows environmental democracy, ENVLAW shows environmental laws, ENVPOL shows environmental politics, ENVREG shows environmental regulations, ESR shows environmental sustainability rating, GOVTEFF shows government effectiveness, and GDPPC shows GDP per capita.

iv) The ease of environmental laws and regulations put many constraints on ecologically sustainable development that need to be effectively controlled by government intervention via carbon taxes and emissions-cap to reduce dirty production. The sustainable strategy calls for more environmentally friendly policies, leading the sustainability ratings more towards progressive development, and

v) Environmental politics is all about politics related to the environment and its long-term sustainability. Environmental challenges cannot be minimized through knowledge and technological spillovers while it remains needed to opt for different environmental politics to fix environmental damages. Political solutions to tackle climate change is the foremost policy agenda to control global average temperature. Creating the international liaison is likely to improve the environmental sustainability agenda, which helps to get shared wisdom and green policies.

The improvement in the environmental sustainability agenda remains a dream for the environmentalists and government officials to make environmentally friendly policies and control dirty production through collaboration and technical expertise. The environmental governance framework is helpful to create a liaison between the community and their stakeholders and give autonomy to make pro-environmental decisions, which reducing negative environmental externalities. Environmental democracy, laws and sustainable regulations are helpful to the way forward towards healthy policies, which stop the rot and making economies more towards pragmatic solutions.

\section{Acknowledgements}

Researchers Supporting Project number (RSP-2022/87), King Saud University, Riyadh, Saudi Arabia.

\section{References}

1. ADAMS D., ADAMS K., ULLAH S., ULLAH F., 2019, Globalisation, governance, accountability and the natural resource 'curse': Implications for socioeconomic growth of oil-rich developing countries, Resources Policy, 61: 128-140.

2. ADEKUNLE I.A., 2021, On the search for environmental sustainability in Africa: the role of governance, Environmental Science and Pollution Research, 28(12): 14607-14620.

3. AGUILERA R.V., ARAGÓN-CORREA J.A., MARANO V., TASHMAN P.A., 2021, The corporate governance of environmental sustainability: A review and proposal for more integrated research, Journal of Management,

DOI: $10.1177 / 0149206321991212$

4. AHMED Z., CARY M., LE H. P., 2021, Accounting asymmetries in the long-run nexus between globalization and environmental sustainability in the United States: an aggregated and disaggregated investigation, Environmental Impact Assessment Review, 86: 106511.

5. ANSER M. K., AHMAD M., KHAN M. A., NASSAN, A. A., ASKAR S. E., ZAMAN K., KABBANI A., 2021, Progress in nuclear energy with carbon pricing to achieve environmental sustainability agenda: on the edge of one's seat, Environmental Science and Pollution Research, DOI: 10.1007/s11356-021-12966-y.

6. ARMINEN H., MENEGAKI A.N., 2019, Corruption, climate and the energy-environment-growth nexus, Energy Economics, 80: 621-634.

7. ASONGU S.A., ODHIAMBO N.M., 2021, Enhancing governance for environmental sustainability in sub-Saharan Africa, Energy Exploration \& Exploitation, 39(1): 444-463.

8. BARBOSA L.G., ALVES M.A.S., GRELLE C.E. V., 2021, Actions against sustainability: Dismantling of the environmental policies in Brazil, Land Use Policy, 104: 105384.

9. BENNETT N.J., SATTERFIELD T., 2018, Environmental governance: A practical framework to guide design, evaluation, and analysis, Conservation Letters, 11(6): e12600.

10. CHENG R., LI W., LU Z., ZHOU S., MENG C., 2020, Integrating the three-line environmental governance and environmental sustainability evaluation of urban industry in China, Journal of Cleaner Production, 264: 121554. 
11. COENEN J., BAGER S., MEYFROIDT P., NEWIG J., CHALLIES E., 2021, Environmental Governance of China's Belt and Road Initiative, Environmental Policy and Governance, 31(1): 3-17.

12. DRESSEL S., SJÖLANDER-LINDQVIST A., JOHANSSON M., ERICSSON G., SANDSTRÖM C., 2021, Achieving Social and Ecological Outcomes in Collaborative Environmental Governance: Good Examples from Swedish Moose Management, Sustainability, 13(4): 2329, DOI: 10.3390/su13042329.

13. GANDA F., 2020, The influence of corruption on environmental sustainability in the developing economies of Southern Africa, Heliyon, 6(7): e04387.

14. GIANNETTI B.F., AGOSTINHO F., ERAS J.C., YANG Z., ALMEIDA C.M.V.B., 2020, Cleaner production for achieving the sustainable development goals, Journal of Cleaner Production, 271: 122127.

15. GIESEKE T., 2020, Collaborative Environmental Governance Frameworks: A Practical Guide. CRC Press, Routledge, Taylor \& Francis Group, UK, https://www.routledge.com/Collaborative-Environmental-Governance-Frameworks-A-Practical-Guid e/Gieseke/p/book/9781138584501\# (16-07-2021).

16. GÖK A., SODHI N., 2021, The environmental impact of governance: a system-generalized method of moments analysis, Environmental Science and Pollution Research, 28: 32995-33008.

17. GUPTA A.C., CHATTERJEE N., 2021, Economic Values for the Environment with Special Reference to the Contingent Valuation Method, Environmental Management: Issues and Concerns in Developing Countries, ed. Sikdar P.K., Springer, Cham, DOI: 10.1007/978-3-030-62529-0_14.

18. GUPTA, A., BOAS I., OOSTERVEER P., 2020, Transparency in global sustainability governance: to what effect?, Journal of Environmental Policy and Planning, 22(1): 84-97.

19. HASEEB M., ZAM M., 2021, Dynamic nexus among tourism, corruption, democracy and environmental degradation: a panel data investigation, Environment, Development and Sustainability, 23(4): 5557-5575.

20. JAGER N.W., NEWIG J., CHALLIES E., KOCHSKÄMPER E., 2020, Pathways to implementation: Evidence on how participation in environmental governance impacts on environmental outcomes, Journal of Public Administration Research and Theory, 30(3): 383-399.

21. JIANG X., LI G., FU W., 2021, Government environmental governance, structural adjustment and air quality: A quasi-natural experiment based on the three-year action plan to win the blue sky defense war, Journal of Environmental Management, 277: 111470.

22. KAGAYA S., WADA T., 2021, The application of environmental governance for sustainable watershed-based management, Asia-Pacific Journal of Regional Science, 5(2): 643-671.

23. KAMAH M., RITI J. S., BIN P., 2021, Inclusive growth and environmental sustainability: the role of institutional quality in sub-Saharan Africa, Environmental Science and Pollution Research, DOI: 10.1007/s11356-021-13125-z.
24. KHAN H., WEILI L., KHAN I., 2021, Environmental innovation, trade openness and quality institutions: an integrated investigation about environmental sustainability, Environment, Development and Sustainability, DOI: 10.1007/s10668-021-01590-y.

25. LAWLESS S., SONG A. M., COHEN P. J., MORRISON T. H., 2020, Rights, equity and justice: a diagnostic for social meta-norm diffusion in environmental governance, Earth System Governance, 6: 100052.

26. LE H. P., SARKODIE S.A., 2020, Dynamic linkage between renewable and conventional energy use, environmental quality and economic growth: evidence from Emerging Market and Developing Economies, Energy Reports, 6: 965-973.

27. LEAL P.H., MARQUES A.C., 2021, The environmental impacts of globalisation and corruption: Evidence from a set of African countries, Environmental Science \& Policy, 115: 116-124.

28. MAZUR K., TOMASHUK I., 2019, Governance and regulation as an indispensable condition for developing the potential of rural areas, Baltic journal of economic studies, 5(5): 67-78.

29. MOUSSA T., KOTB A., HELFAYA A., 2021, An Empirical Investigation of UK Environmental Targets Disclosure: The Role of Environmental Governance and Performance, European Accounting Review, DOI: 10.1080/09638180.2021.1890173

30. MURSHED M., RAHMAN M.A., ALAM M.S., AHMAD P., DAGAR V., 2021, The nexus between environmental regulations, economic growth, and environmental sustainability: linking environmental patents to ecological footprint reduction in South Asia, Environmental Science and Pollution Research, DOI: 10.1007/s11356-021-13381-z.

31. NGUYEN B., 2021, Does Local Environmental Governance Improve Tourism Companies' Performance? Evidence from Vietnam, Journal of Travel Research, DOI: 10.1177/00472875211002653.

32. PASGAARD M., VAN HECKEN G., EHAMMER A., STRANGE N., 2017, Unfolding scientific expertise and security in the changing governance of Ecosystem Services, Geoforum, 84: 354-367.

33. PEKER E., ATAÖV A., 2021, Governance of Climate Responsive Cities: Scale Matters!, Governance of Climate Responsive Cities. The Urban Book Series, eds. Peker E., Ataöv A., Springer, Cham, DOI: 10.1007/978-3-030-73399-5_1.

34. PICKERING J., BÄCKSTRAND K., SCHLOSBERG D., 2020, Between environmental and ecological democracy: theory and practice at the democracy-environment nexus, Journal of Environmental Policy \& Planning, 22(1): 1-15.

35. QUANDT R.E., 1972, A new approach to estimating switching regressions, Journal of the American statistical association, 67(338): 306-310.

36. QURESHI M.I., QAYYUM S., NASSAN A.A., ALDAKHIL A.M., ABRO M.M.Q., ZAMAN K., 2019, Management of various socio-economic factors under the United Nations sustainable development agenda, Resources Policy, 64: 101515.

37. RAJESH, R., 2020, Exploring the sustainability performances of firms using environmental, social, and governance scores, Journal of Cleaner Production, 247: 119600. 
38. RAJESH, R., RAJENDRAN, C., 2020, Relating environmental, social, and governance scores and sustainability performances of firms: An empirical analysis, Business Strategy and the Environment, 29(3): 1247-1267.

39. RAJMOHAN K.V.S., RAMYA C., VISWANATHAN M.R., VARJANI S., 2019, Plastic pollutants: effective waste management for pollution control and abatement, Current Opinion in Environmental Science \& Health, 12: 72-84.

40. RAMZAN S., LIU C., MUNIR H., XU Y., 2019, Assessing young consumers' awareness and participation in sustainable e-waste management practices: a survey study in Northwest China, Environmental Science and Pollution Research, 26(19): 2000320013.

41. REED G., BRUNET N.D., LONGBOAT S., NATCHER D.C., 2021, Indigenous guardians as an emerging approach to indigenous environmental governance, Conservation Biology, 35(1): 179-189.

42. SAVAGE J.M., HUDSON M.D., OSBORNE P.E., 2020, The challenges of establishing marine protected areas in South East Asia, Marine protected areas, Elsevier:343-359.

43. SUN H., MOHSIN M., ALHARTHI M., ABBAS Q., 2020, Measuring environmental sustainability performance of South Asia, Journal of Cleaner Production, 251: 119519.

44. TACCONI L., WILLIAMS D.A., 2020, Corruption and Anti-Corruption in Environmental and Resource Management, Annual Review of Environment and Resources, 45: 305-329.

45. TAN Y., GENG Y., 2020, Coupling coordination measurement of environmental governance: case of China, Environmental and Ecological Statistics, 27(2): 253-272.

46. THALER G.M., 2021, Ethnography of environmental governance: Towards an organizational approach, Geoforum, 120: 122-131.

47. USMAN O., OLANIPEKUN I.O., IOREMBER P. T., ABU-GOODMAN M., 2020, Modelling environmental degradation in South Africa: the effects of energy consumption, democracy, and globalization using innovation accounting tests, Environmental Science and Pollution Research, 27(8): 8334-8349.

48. VAN ASSCHE K., BEUNEN R., GRUEZMACHER M., DUINEVELD M., 2020, Rethinking strategy in environmental governance, Journal of Environmental Policy \& Planning, 22(5): 695-708.

49. WANG S., WANG H., WANG J., YANG F., 2020, Does environmental information disclosure contribute to improve firm financial performance? An examination of the underlying mechanism, Science of the Total Environment, 714: 136855.

50. WGI 2021, World governance indicators, World Bank, Washington D.C.

51. WILLIAMS A., DUPUY K., 2017, Deciding over nature: Corruption and environmental impact assessments, Environmental Impact Assessment Review, 65: 118-124.

52. WORLD BANK 2021, World development indicators, World Bank, Washington D.C.

53. ZAMAN K., AZIZ A.R.A., SRIYANTO S., INDRIANTI Y., JAMBARI H., 2021, The role of solar energy demand in the relationship between carbon pricing and environmental degradation: A blessing in disguise, Journal of Public Affairs, e2702.
54. ZHANG J., CHANG Y., ZHANG L., LI D., 2018, Do technological innovations promote urban green development? - A spatial econometric analysis of 105 cities in China, Journal of cleaner production, 182: 395-403.

\section{Appendix}

Table A: List of Countries

Coun- Azerbaijan, Belgium, Benin, Burkina Faso, tries Barbados, South Sudan, Chile, China, Côte

(67) d'Ivoire, Congo, Rep., Colombia, Germany, Spain, United Kingdom, Georgia, Ghana, Guinea, Equatorial Guinea, Guatemala, Guyana, Honduras, Japan, Kazakhstan, Kenya, Kyrgyz Republic, Korea, Rep., Lao PDR, Liberia, St. Lucia, Liechtenstein, Luxembourg, Macao SAR China, Morocco, Moldova, Mexico, North Macedonia, Malta, Mongolia, Mozambique, Malawi, Malaysia, Namibia, Niger, Nicaragua, Pakistan, Portugal, Paraguay, Romania, Russian Federation, Samoa, Saudi Arabia, Singapore, Slovak Republic, Slovenia, Seychelles, Chad, Togo, Timor-Leste, Tonga, Trinidad and Tobago, Tanzania, Uganda, United States, Uzbekistan, Vietnam, Vanuatu, West Bank and Gaza. 